\title{
ベトナム・ハノイ市のため池からの浸透による 地下水七素污染の評価
}

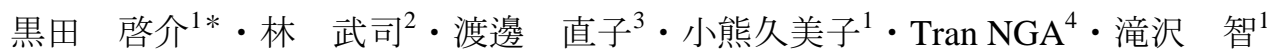 \\ ${ }^{1}$ 東京大学大学院工学系研究科（广113-8656 文京区本郷7-3-1) \\ 2秋田大学教育文化学部（ $\bar{T} 010-8502$ 秋田県秋田市手形学園町 $1-1$ ) \\ ${ }^{3}$ 北海道大学大学院工学研究科 ( $\bar{T} 060-8628$ 北海道札幌市北区北13条西 8 丁目)
}

${ }^{4}$ National University of Civil Engineering, IESE, DHXD, 55 Giai Phong Street, Hanoi, Viet Nam

* E-mail: $k \_k u r o d a @ e n v . t . u$-tokyo.ac.jp

\begin{abstract}
ヒ素による地下水污染が深刻なベトナム・ハノイ市郊外にはため池が多く存在する。本研究では、八ノ イ市郊外の4つのため池において、池の水質、底質間隙水の水質、底質の化学性状を調查し、ため池から の浸透水が地下水水質に及ぼす影響を推定した。七素濃度は、池水中では $10 \mu \mathrm{g} / \mathrm{L}$ 以上低かったが、底 質間隙水中では最大 $134 \mu \mathrm{g} / \mathrm{L}$ と高かった。底質は有機物や七素の含有量が高く、底質からの七素の溶出が

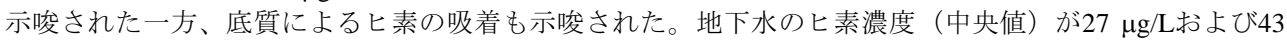
$\mu \mathrm{g} / \mathrm{L}$ と高かった地域は、塩化物イオン濃度や安定同位体比からため池浸透水からの涵養量が大きいことが 示唆され、高濃度のヒ素やDOCを含むため池浸透水が地下水の七素污染に寄与している可能性が示された。
\end{abstract}

Key Words : arsenic, groundwater, organic matter, pond, sediment, pore water, Viet Nam

\section{1. はじめに}

ベトナムの首都であるハノイ市の人口は現在 600 万 人を超え、2030 年には現在より $43 \% 、 2050$ 年には現在 より $68 \%$ 増加すると見込まれている ${ }^{1)}$ 。現在、ハノイ 市の水供給は地下水を主要な水源としているが、地下水 位の低下や地盤沈下等の問題から、1997 年から表流水 の利用を開始し、表流水からの供給量を増加することで、 急速に郊外一と拡大寸る都市域の水需要の増加に対応す る計画である ${ }^{1)}$ 。しかしながら、浄水場の拡張や送配水 設備の整備が遅延していることもあり、地下水は今後も 八ノイ市の重要な水資源となることが予想される。

ハノイ市の地下水は、七素を始めとして、鉄、有機 物、アンモニア性窒素等の様々な物質に污染されてい ることが知られている ${ }^{24)}$ 。特に、地下水の七素污染は 深刻であり、WHO の飲料水水質ガイドラインである 10

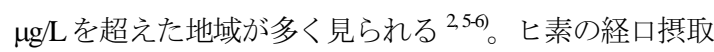
は、皮膚の硬化、内蔵の損傷、がんの発生など、人体 に不可逆的な悪影響を引き起こす7。ハノイ市では家庭 に備えた砂ろ過装置や RO 装置で地下水や水道水を処
理して飲用等に用いることが多いが、ヒ素等の污染物 質が必ずしも効果的に除去されているとは限らない ${ }^{8-9}$ 現在のところ、ハノイ市ではヒ素中毒の症状は出てい ないものの、将来における慢性七素中毒が懸念されて おり、地下水七素污染の抑制や家庭での浄水方法の改 善が求められている。

七素による地下水污染は世界の多くの地域で大きな 問題となっている。東南アジア及び南アジアにおいて は、一般に、地下水中の七素はヒマラヤ山脈を起源と する堆積物に由来し、還元環境において鉄酸化物に吸 着していたヒ素が溶出することがヒ素污染の原因と考 えられている ${ }^{10}$ が、土袞中に埋もれている過去の植物 の根に濃集されたヒ素が溶出している可能性も指摘さ

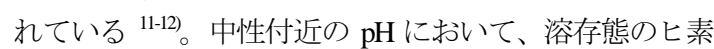
は $\mathrm{H}_{2} \mathrm{As}(\mathrm{V}) \mathrm{O}_{4}^{-}$または $\mathrm{H}_{3} \mathrm{As}(\mathrm{III}) \mathrm{O}_{3}$ の形態で存在し ${ }^{13)}$ 、七素 の溶出過程ではヒ素(V)がより移動性の高いヒ素(III) 一 還元されていると言われている ${ }^{10)}$ 。これらの還元反応 は微生物の働きにより起こるため、有機物の分解を伴 う。七素濃度の高、地下水には無機炭素、アンモニア、 メタンなど、微生物反応の代謝産物が多く含まれる ${ }^{10)}$ 
鉄(III)や七素(V)の還元に必要な有機物は大きく分け て二つの経路によって地下水中にもたらされると考え られている。一つは土着の有機物であり、堆積物中に

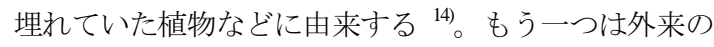
有機物であり、表層に近いより新しい年代の地層や有 機物含有量の多いピート層に由来する DOC が地下水の 流れによりもたらされたものである ${ }^{15-10}$ 。一般に、表層 に近い地層や堆積物は有機物を多く含み、地層中での ヒ素の還元的溶出において重要な役割を果たすと考え

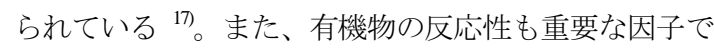
あり ${ }^{18-199}$ 、湿地のような、反応性が高く、分解しや寸い 有機炭素が存在する堆積物中ではヒ素の溶出速度は大 きく、有機炭素の反応性が低い場合の溶出速度は小さ (10)。地下水中の溶存態無機炭素は DOC より年代が若 いというデータから、七素の溶出には新しい年代の有 機物が寄与している可能性が指摘されている ${ }^{15}$, 17)。た め池から浸透する水には分解しや寸い DOC の割合が 30-50\%程度と多く含まれるのに対し、水田から浸透す る水ではその割合が低い(<10\%)という報告がある ${ }^{20)}$ 。

八ノイ市の帯水層には完新世（約 1 万年前～現在） の堆積物である上部帯水層と、更新世（約 258 万年前 〜約 1 万年前）の堆積物である下部帯水層がある。地 下水中の七素濃度は一般に上部帯水層において高いと されるが、近年では下部帯水層において過度な揚水に より水理水頭が低下したため、上部帯水層の水の混入 により下部帯水層の七素濃度が上昇したとも言われて いる ${ }^{21}$ 。八ノイ市の地下水は市内を縦断する大河川で ある紅河により主に涵養されるとされている ${ }^{5,21-22) か ゙ 、 ~}$ 近年の研究では、ため池や水田等、蒸発を受けた表流 水が地下水涵養に大きく寄与している可能性が指摘さ れている ${ }^{21,23-24)}$ 。

ため池は八ノイ市郊外に多く点在しており、旧河川 に由来して自然に形成されたものと、人工的に作られ たものがあり、雨水や污水の廃棄場所、養魚場、釣り 堀等、複数の機能を持つものが多い。ため池は様々な 廃水を受け入れており、污染物質を分解・処理寸る機 能を有すると考えられる。ため池の水は概して污濁が 進み、池底には河川堆積物に加え、周辺の土や塵埃、 生活排水由来の污泥、プランクトン等の動植物の死骸 が堆積し、有機物が多く存在することが考えられる。 このため、仮にため池から地下への浸透水の地下水涵 養に対する寄与が大きい場合、有機物濃度が高いと予 想されるため池浸透水は、周辺の地下水における七素 污染の拡大に寄与している可能性がある。しかしなが ら、ハノイ市におけるため池の底質の化学的性状や、 底質における有機物や重金属類の移動・濃集・溶出機 構、ため池浸透水の水質を調べた例はなく、ため池浸
透水が地下水水質へ及ぼす影響は不明である。

そこで本研究では、ハノイ市郊外の 4 地域において、 ため池の水質、底質間隙水の水質、底質の化学組成を 調查し、同じ地域の地下水の既存の調查結果 ${ }^{25}$ ) 比較 することで、ため池の水質形成機構、ため池底質にお ける物質の移動・濃集・溶出機構、ため池から地下 浸透する水の水質や挙動を明らかにし、ため池浸透水 が地下水水質に及ぼす影響を推定した。

\section{2. 調査方法}

\section{(1) 調査地域と地形の概要}

ハノイ市はベトナム北部の紅河デルタの上流部に位置 している。紅河デルタの地形は複数回の海進・海退によ って形成され、下部帯水層となっている更新世の砂・砂 礫層が、完新世の厚い難透水性の粘土質の堆積物に覆わ れている地質構造が典型的である。完新世の堆積物には 天然の有機物(NOM)が多く含まれており、有機物の豊富 なピート層は場所により $10 \mathrm{~m}$ 以上と厚い ${ }^{26}$ 。また海成の 堆積物も見られる ${ }^{27}$ 。繰り返される堆積過程によって、 堆積物の層相は非常に複雑であり、小さな地域内でも層 相が大きく異なることがある27)

本研究の調查地域はハノイ市郊外にあるThuong Cat (TCと略す。以下同様)、Sap Mai (SM)、Tay Mo (TM)、 Ngoc Hoi (NH)の計4地区である（図-1）。各地区のそれ ぞれ1ヶ所のため池（それぞれ、ため池TC、ため池SM、 ため池TM、ため池NHとする）を調查対象とした。た め池の面積はそれぞれおよそ20,000、7,000、6,000、 11,000 $\mathrm{m}^{2}$ であり、深さはいずれも1-2 mである。調査し

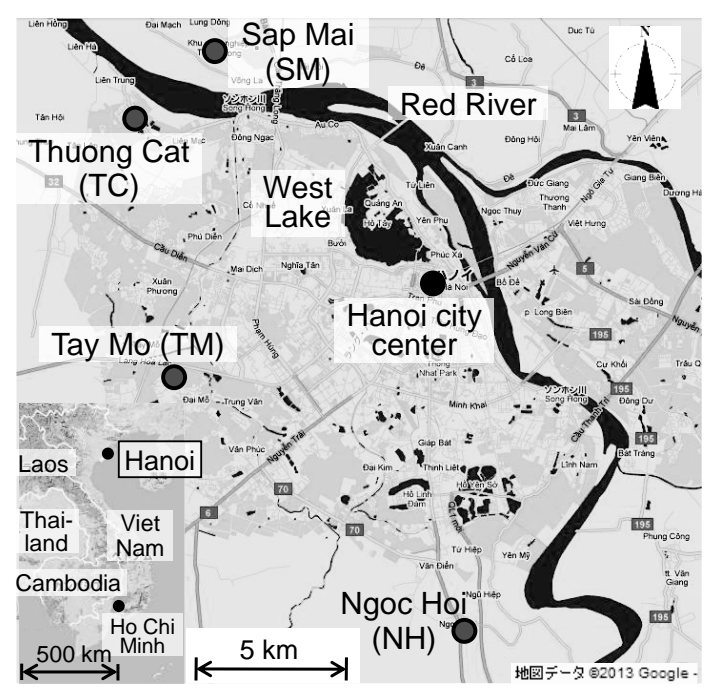

図-1 調查地域 
たため池は主に雨水や生活雑排水の廃棄場として使用 されている。ため池TCは周辺に田畑が存在し、揚水用 ポンプは存在しないが、灌溉用水がため池に流入して いる可能性がある。他のため池は住宅地内にある。た め池NHは養豚場が隣接しており畜産排水の廃棄場所に もなっている。いずれのため池も農業用水には利用さ れておらず、年間を通して常に水が存在し、八スを始 めとした水生植物が繁茂している。池干しや底泥の浚 渫は行われていない。

\section{(2) 水及び底質試料の採取}

2011年3月に上記のため池の湖心において直径 $5 \mathrm{~cm} の$ 塩ビ管を池底に貫入し、深さ $1 \mathrm{~m}$ 程度の底質を各池で2 本ずつ不擋乱状態で採取した。さらに、2011年8月にた め池NHにおいて再度底質を同様に2本採取した。この うち、一本の採取地点は2011年3月の底質採取地点之同 じ位置であり、もう一本の採取地点は20-30 m程度離れ ている。ため池TC、SM、NHの底質はシルトであり、 ため池TMでは池底から深さ0-87 cmがシルト、深さ87$100 \mathrm{~cm} ゙$ より締まっているシルト及び粘土であった。 いずれのため池においても池底に近い底質上部は含水 率の高い軟泥であった。

2011年3月に採取した底質に関しては、底質を塩ビ管 に入れたまま開封せずに室温保存で日本一持ち帰り、

速やかに遠心分離機（KUBOTA、7780II）を用い, $\mathrm{pF} 3.0$ 相当の回転数で 30 分間、およびpF4.2相当の回転数で60 分間、遠心分離を行い、底質試料から深さ $10 \mathrm{~cm}$ ごとの 底質間隙水を得た。この遠心分離により得られる水は いずれも土近傍に吸着あるいは拘束されていない自由 水であるが、 $\mathrm{pF} 3.0$ では土粒子と弱い力で結合していて 植物が利用可能な水が、 $\mathrm{pF} 4.2$ では土粒子とより強い力 で結合していて植物が利用できない水を含んでいる ${ }^{28)}$ 2011年8月に得た底質に関しても2011年3月採取の底質 と同様に未開封のまま塩ビ管ごと室温保存で日本一持 ち帰り、まず土畩溶液抽出採水器（Eijkelkamp、Rhizon sampler）を用いて深さ $10 \mathrm{~cm}$ ごとに間隙水を採取した。 この方法により得た間隙水は $\mathrm{pF} 2.3$ 程度である (Eijkelkamp)。さらに、2011年3月に採取した底質試料 と同様にpF3.0およびpF4.2相当の回転数で遠心分離を行 、底質試料から深さ $10 \mathrm{~cm}$ ごとの底質間隙水を得た。

また、2011年の3月、8月、10月および2012年の1月、3 月、6月、8月に、各ため池の表層部の水を最大7回にわ たり採水し計22試料を得た。2011年8月には、ため池 NH の湖心において同一位置で深さ方向の池水を同時に採 取した。採水した深さは、 $0 \mathrm{~m}$ （表層部）、0.5 m、 $1.0 \mathrm{~m}$ 、 $1.5 \mathrm{~m}$ (池底部) であった。

さらに、2011年3月から同年10月に各ため池周辺の3- 10ヶ所の家庭用井戸（深さ20-70m）で計26試料の地下 水を採取し水質を分析した ${ }^{2425)}$ 。水質分析方法は池水と 同じで下記に示すとおりである。

\section{(3) 水質分析}

全ての試料水は原則として採取後すみやかに孔径 0.45 $\mu \mathrm{m}$ PTFE膜によりろ過し分析に供した。土垬溶液抽出 採水器によって得た試料は、採水時に採水器に備わっ ている $0.2 \mu \mathrm{m}$ 膜を通過しているので、そのまま分析に 供した。

池水の酸化還元電位（Eh）および溶存酸素（DO）に 関しては、ろ過せずに現場で採取後すみやかにポータ ブルEh計（東亜DKK、RM-20P）及びポータブル溶存酸 素計（Hach、HQ30d）によりそれぞれ測定した。アン モニア性窒素 $\left(\mathrm{NH}_{4}-\mathrm{N}\right)$ は現場で吸光光度計（Hach、 DR890）を用いたサリチラート法により分析した。

陰イオン、ヒ素、鉄、溶存態有機炭素（DOC）、安 定同位体比は試料水を冷蔵保存して日本に持ち帰り分 析した。陰イオン $\left(\mathrm{Cl} 、 \mathrm{NO}_{2}^{-} 、 \mathrm{NO}_{3}^{-} 、 \mathrm{PO}_{4}^{3{ }^{-}} 、 \mathrm{SO}_{4}{ }^{2-}\right)$ はイ オンクロマトグラフィー (Metrohm、761Compact IC ; カ ラム：Shodex、SI-90）で測定した。ヒ素及び鉄は現場 で濃硝酸を $1 \%$ （v/v) 添加後、スカンジウムおよびガリ ウムを内部標準物質として ICP-MS（Agilent、ICPMS7500cx）により分析した。DOCは現場で塩酸を $1 \%$ $(\mathrm{v} / \mathrm{v})$ 添加後、TOC計（島津製作所、TOC-V、NPOC 法）により分析した。試料水の酸素及び水素の安定同 位体比 $\left(\delta^{18} \mathrm{O} 、 \delta \mathrm{D}\right)$ は分析に必要な液量を確保できた $\mathrm{pF} 4.2$ の試料を用い、（株）地球科学研究所（名古屋 市）にて近赤外線レーザー法により分析した。水の同 位体比は蒸発や凝縮などの相変化により変化するため、 水の起源や流動環境について情報が得られ29)、ハノイに おいては河川やため池など地下水の涵養源の推定に有 用である ${ }^{24)}$ 。水の酸素水素同位体比はVSMOW（Vienna Standard Mean Ocean Water) を標準として一般に次の式 (1a)のように表される。

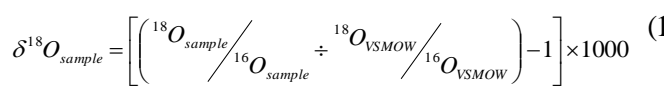

\section{(4) 底質分析}

2011年3月に採取した底質を日本で以下の通り分析し た。底質の含水率は、遠心分離前後の底質の重量差に、 遠心分離後の底質を $110^{\circ} \mathrm{C}$ で24時間以上乾燥させた前後 の重量差を加えて得た。底質の有機物は $450^{\circ} \mathrm{C} て ゙ 16$ 時間 乾燥させた前後の重量差により測定した。底質の金属 含有量は、風乾・破砕した底質を硝酸と過酸化水素を 用いたマイクロウェーブ熱分解法（EPA3050B）により 
分解後、希釈し、内部標準物質 (スカンジウム、ガリ ウム）を加えてICP-MS（Agilent、ICP-MS7500cx）によ り分析した。マイクロウェーブ熱分解法及びICP-MS分 析における分析精度を底質分析用標準物質（National Institute of Standards \& Technology、SRM-1944）を用いて検 証したところ、回収率（n=4）はヒ素が $100 \% \pm 3 \%$ 、鉄が $94 \% \pm 4 \%$ あり、分析精度は十分といえた。

\section{3. 結果}

\section{(1) 池水の水質}

図-2に表層部で採取した池水におけるヒ素、鉄、 DOC、アンモニア性窒素、塩化物イオンの各濃度とEh を示した。また、各ため池周辺で採取した地下水の測 定值の中央值 ${ }^{25}$ を併せて示した。

池水・地下水の水質は地区により異なる傾向を示し ており、特に地下水では地区間の差が顕著であった。 池水は、いずれのため池でも $\mathrm{Eh}$ が $300 \mathrm{mV}$ 程度あり、鉄 濃度も0.3 mg/L以下と低く酸化的な環境にあった。ヒ素 濃度は数 $\mu \mathrm{g} / \mathrm{L}$ 程度と概して低く、WHOガイドライン值 の10 $\mu \mathrm{g} / \mathrm{L}$ 超えた試料は22試料中1試料のみであった。 一方、地下水は地区TCを除き $\mathrm{Eh}$ が $100 \mathrm{mV}$ 前後と低く、 鉄濃度が $5 \mathrm{mg} / \mathrm{L}$ 超える還元的な環境にあった。ヒ素濃 度は、酸化的な地下水である地区TCにおいては $1 \mu \mathrm{g} / \mathrm{L}$ 以下と低いのに対し、還元的な他の地区の地下水では
高濃度であり、地区SMにおいては中央值が $10 \mu \mathrm{g} / \mathrm{L}$ 程度、

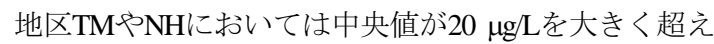
ており、池水のヒ素濃度を大きく上回っていた。

これらの地下水では、ヒ素濃度がWHOガイドライン 值の10 $\mu \mathrm{g} / \mathrm{L}$ 超えた地下水試料の割合は地区TC、SM、 TM、NHでそれぞれ0\%、33\%、100\%、94\%であり、複 数の文献 ${ }^{4,21,30)}$ でも示されているように、地下水のヒ素 污染の程度が場所により大きく異なっていた

DOCは池水において $5 \mathrm{mgCl}$ を超える高濃度の試料が 大半であり、地下水中のDOC濃度（1-3 mgC/L）より全 般的に高かった。塩化物イオンは、池水の濃度の中央 值は10-61 mg/Lと池間の差が大きく、同一の池において も試料間のばらつきが大きかったが、ため池TMを除く ため池TC、SM、NHにおいては池水中濃度が地下水中 濃度（1.4-22 mg/L）を大きく上回っていた。池水のア ンモニア性窒素濃度はため池TCおよびTMにおいては低 い（<1 mgN/L）一方、ため池SMとNHにおいては10 $\mathrm{mgN} / \mathrm{L}$ 超える試料が存在した。地下水では、酸化的 環境にある地区TCではほとんど検出されなかったが、 地区SM、TM、NHでは中央值がそれぞれ1.5、5.0、8.5 $\mathrm{mgN} / \mathrm{L}$ 高い濃度も見られた。池水のDOC、塩化物イ オン、アンモニア性窒素は、ため池間で明確な傾向は 見られないが、ため池NHにおいてこれらがきわめて高 濃度の試料が存在した。この理由の一つにはため池NH に流入する畜産排水が考えられる。一方、地下水では ヒ素、DOC、アンモニア性窒素、塩化物イオン濃度の
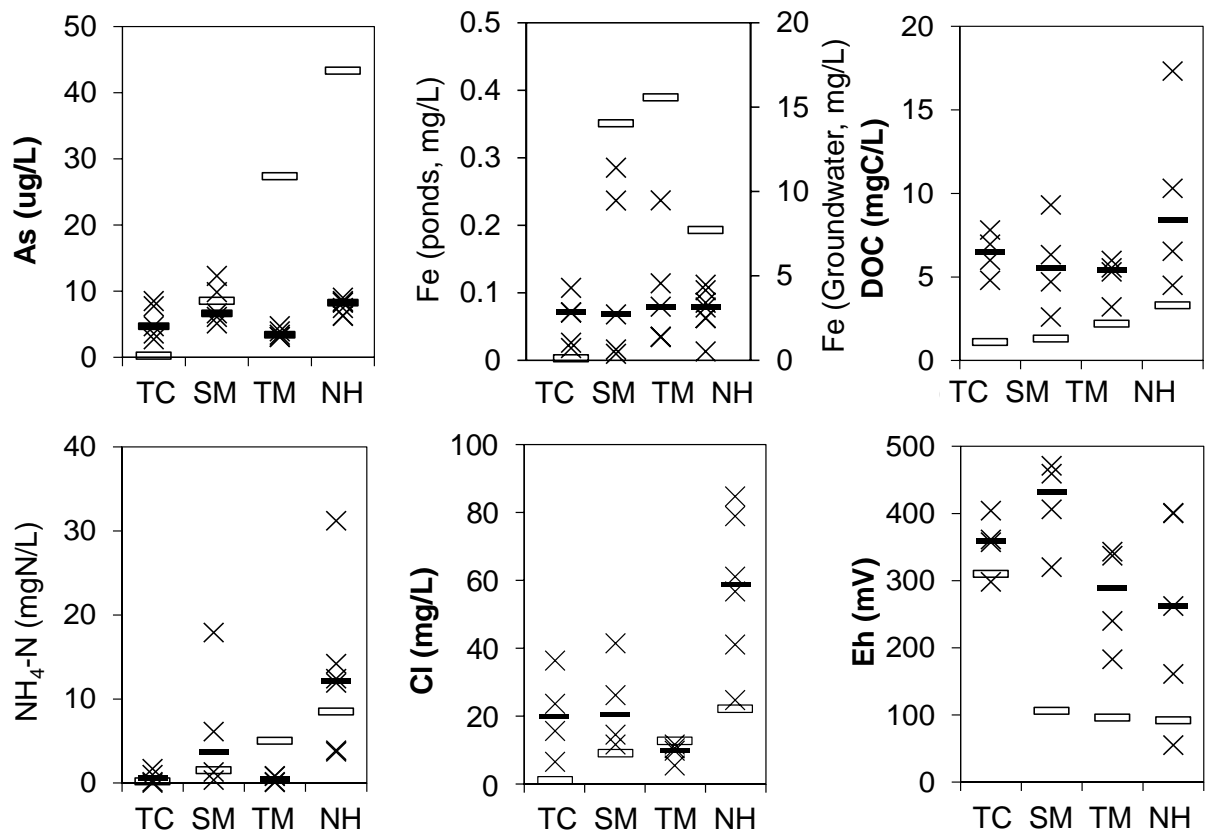

X Pond water

TC SM TM NH

TC SM TM NH

図-2 池水と地下水の水質 
各地区の中央值が、地区TC、SM、TM、NHの順に濃度 が高くなる傾向が共通して見られた。

硫酸イオン、硝酸イオン、リン酸イオンの濃度は池 水でそれぞれ4.8-24 mg/L、0-12 mg/L、0-12 mg/L、地下 水でそれぞれ0-16 mg/L、0-4.6 mg/L、0-1.9 mg/Lであっ た。 $1 \mathrm{mg} / \mathrm{L}$ 以上の高いリン酸イオン濃度はため池 SM、 ため池NH、地区NHの地下水で検出された。亜硝酸イ オンは地下水では検出されず、池水では最大 $3.6 \mathrm{mg} / \mathrm{L} て ゙$ 検出された。

池水水質には季節変動が存在した。特に塩化物イオ ン濃度に明確に見られ、6月、8月、10月に採水した試 料は濃度が低く、1月及び3月の試料で濃度が高かった。 ヒ素、DOC、アンモニア性窒素の季節変動は塩化物イ オンと同様の傾向を示したが、変動幅は小さく、季節 変動はやや不明確であった。

ため池NHにおける深度別の採水調査においては、 DOは水面から深度 $1.5 \mathrm{~m}$ までで $14 \mathrm{mg} / \mathrm{L}$ から $0.22 \mathrm{mg} / \mathrm{L}$ と濃 度が大きく減少していたが、Ehは全ての深さで40-74 $\mathrm{mV}$ の值をとり、深さ方向の変化は見られなかった。七 素、鉄、DOC、塩化物イオンは、深さ0-1.5 mの濃度の 標準偏差が2\%-20\%と比較的大きな変化はなかったが、 全て深さ $1.5 \mathrm{~m}$ において最も濃度が高く、それぞれ8.6 $\mu \mathrm{g} / \mathrm{L} 、 0.1 \mathrm{mg} / \mathrm{L} 、 12 \mathrm{mgC} / \mathrm{L} 、 63 \mathrm{mg} / \mathrm{L}$ あ゙あった。これらの 濃度は深さ0-1.0 mの平均值から4\%-20\%の乘離があった

\section{(2) 底質間隙水の水質}

図-3a)および図-3b)に2011年3月に4地区のため池底質 から採取した間隙水中のヒ素、アンモニア性窒素、

DOC、鉄、塩化物イオンの濃度を池底からの深さと共 に示した。ヒ素とアンモニア性窒素は、pF3.0の間隙水 に比べpF4.2の間隙水の濃度が高い傾向が見られ、最大 で2倍程度の差があった。七素濃度の深度分布はため池 ごとに異なっており、ため池SMおよびため池TMでは 池底面に最も近い部分（底質最上部）の試料でそれぞ れ85 $\mu \mathrm{g} / \mathrm{L} 、 43 \mu \mathrm{g} / \mathrm{L}$ と高いヒ素濃度を示したが、これよ り $10 \mathrm{~cm}$ 深い位置の試料ではヒ素濃度が $25 \mu \mathrm{g} / \mathrm{L}$ 程度まで 低下し、これ以深はゆるやかに減少する傾向があった。 ため池TCでは底質最上部における七素濃度が $19 \mu \mathrm{g} / \mathrm{L}$ と 他のため池に比べ比較的低く、深度と共にヒ素濃度は ゆるやかに低下した。これらに対し、ため池NHでは底 質最上部から梁さ30 cmまでの範囲ではヒ素濃度が20 $\mu \mathrm{g} / \mathrm{L}$ 前後であるが、 $30 \mathrm{~cm}$ 以深でヒ素濃度が急上昇し、 最大で82 $\mu \mathrm{g} / \mathrm{L}$ の高いヒ素濃度が検出された。ため池 NH の底質間隙水では、七素と同様にアンモニア性窒素も $30 \mathrm{~cm}$ 以深で濃度が急上昇しており、最大 $135 \mathrm{mgN} / \mathrm{L}$ と顕 著に高濃度であった。ため池TC、SM、TMの底質間隙 水中アンモニア性窒素濃度は、地区NHの濃度と比べる
と低いものの、 $\mathrm{pF} 4.2$ 間隙水で7.2-41 mgN/Lとやはり高 濃度であった。DOC濃度は概して深さとともに増加す る傾向にあり、底質底部では20-40 m CC/Lと極めて高濃 度であった。DOCは多くの試料でpF3.0の間隙水に比心゙ $\mathrm{pF} 4.2$ 間隙水の濃度が高い傾向が見られたが、ため池 TCおよびNHではpF3.0の間隙水において $60 \mathrm{mgC/L}$ を超え る顕著に高濃度の試料が存在した。

以上のように、底質間隙水は概してヒ素やアンモニ ア性窒素濃度が高く、強い還元環境が示唆された一方、 鉄濃度は $2 \mathrm{mg} / \mathrm{L}$ 以下と低く、 $\mathrm{pF} 3.0$ と $\mathrm{pF} 4.2$ の大小関係も 不明瞭であった。その理由として、後述するとおり、 遠心分離作業中に鉄の酸化による濃度低下が起こった と考えられる。塩化物イオンは $\mathrm{pF3}$.0の間隙水と $\mathrm{pF} 4.2$ の 間隙水の濃度がほぼ等しく、ため池NHでは深さととも に濃度が増加した一方、他のため池では深さ方向にほ ぼ一定濃度を示した。間隙水の硫酸イオン濃度は0.2-33 $\mathrm{mg} / \mathrm{L}$ とばらつきがあるが、各ため池ごとに深さ方向の 濃度変化が異なっており、明確な傾向が見られなかっ た。硝酸および亜硝酸イオンは低濃度 (2.2 mg/L以下) であった。リン酸イオンは、 NHの底質上部（3.6 $\mathrm{mg} / \mathrm{L})$ 以外は検出限界 $(0.1 \mathrm{mg} / \mathrm{L})$ 以下であった。

図-3c)に、2011年8月にため池NHで採取した2本の底質 試料（NH1、NH2 とする）から得た間隙水の水質の深 度分布を示す。NH1の採取地点は2011年3月の底質採取 地点と同じ位置である。 $\mathrm{NH} 1 、 \mathrm{NH} 2$ ともに、土壌溶液 抽出採水器で採取したpF2.3相当の間隙水中においては $10 \mathrm{mg} / \mathrm{L}$ 超える高濃度の鉄が検出された。このような 高濃度の鉄は上記に見られた間隙水の還元性の高い環 境と調和的である。土袞溶液抽出採水器は採水管を直 接底質に24時間挿入し引圧により間隙水を得るもので、 外気との接触を最小限にすることができる ${ }^{31}$ 。2011年3 月に採取した間隙水においては、間隙水採取前に間隙 水中に溶存していた鉄(II)が遠心分離作業中に空気に触 れることにより鉄(III)へと酸化し、底質固相や機器等に 付着するなどして溶存態中から失われたと考えられる。 $\mathrm{NH} 1$ と NH2において、土壌溶液抽出採水器による採水 後の遠心分離により得た間隙水中では鉄濃度が $1.5 \mathrm{mg} / \mathrm{L}$ 以下と低く、遠心分離作業中の酸化が示唆された。

NH1およびNH2の間隙水中のヒ素濃度は最大 $134 \mu \mathrm{g} / \mathrm{L}$ と高濃度であった。2011年3月調查時に見られたため池 $\mathrm{NH}$ 底質下部における高濃度の七素と塩化物イオンや、 深さ20-30 cmにおける間隙水中の顕著に高いDOC濃度 は、NH1およびNH2においても見られた。一方、2011年 3月の調査時には、ヒ素やアンモニア性窒素がpF3.0に比 べてpF4.2の間隙水中で高濃度の傾向が見られたが、 NH1およびNH2においてはそのような傾向は特に見ら れず、 $\mathrm{pF} 2.3$ の間隙水が最も七素濃度が高い試料が存在 
した。アンモニア性窒素はpF2.3、pF3.0、pF4.2の間でほ ぼ同じ濃度であった。このような違いには、採水時に おける間隙水の酸化が一因と考えられる。2011年3月時 には、底質が入った塩ビ管を開封後、すぐに遠心分離 を行ったのに対し、2011年8月時には塩ビ管を開封後に 土㙵溶液抽出採水器による採水を24時間行い、その後 に遠心分離を行ったことから、pF3.0および゙F4.2の間隙 水は2011年3月時より酸化が進んでいた可能性がある。

\section{(3) 底質の化学組成}

図-4に2011年3月に採取した各地区のため池底質にお ける水分含有量 $(\%)$ 、 Eh $(\mathrm{mV})$ と、乾燥重量に対寸
る七素含有量 $(\mathrm{mg} / \mathrm{Kg})$ 、鉄含有量 $(\%)$ 、有機物含有 量 $(\%)$ を深さ方向に示した。水分含有量は底質最上 部では66-85\%と高く、深さと共に減少していた。Ehは どのため池でも底質上部が最も低く $0 \mathrm{mV}$ と還元的にな っており、深さとともにばらつきはあるがEhはやや増 加し酸化的になっていた。七素含有量は地区によって やや差が見られ、地区TC、SM、TMにおいては底質最 上部においてはヒ素含有量が最も高く、深さと共にヒ 素含有量が減少していったが、地区NHでは深さに伴う 七素含有量の顕著な減少は見られなかった。七素含有 量は底質最上部において11-16 mg/Kg、最下部において 4.3-14 mg/Kgであった。既存の文献におけるハノイの土

a) Ponds TC and SM (March 2011)

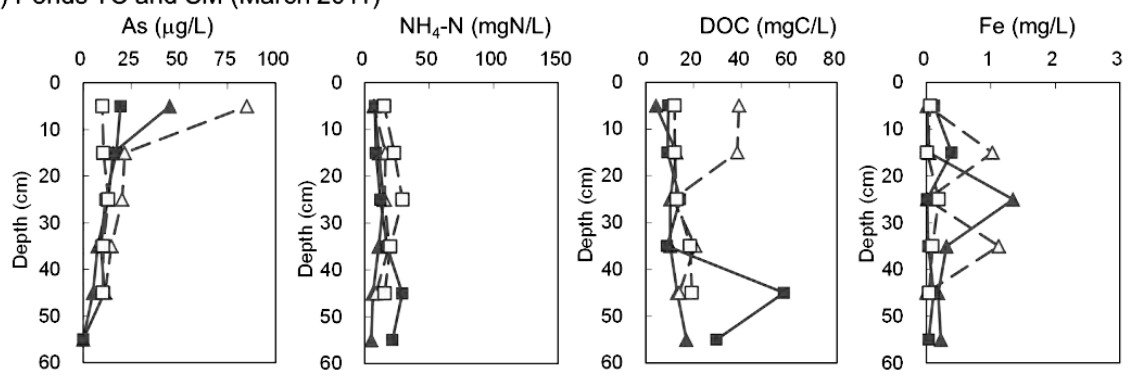

들-TC pF3.0 - - TC pF4.2 $\simeq$ SM pF3.0 - $\Delta-\mathrm{SM} \mathrm{pF4.2}$

b) Ponds TM and NH (March 2011)
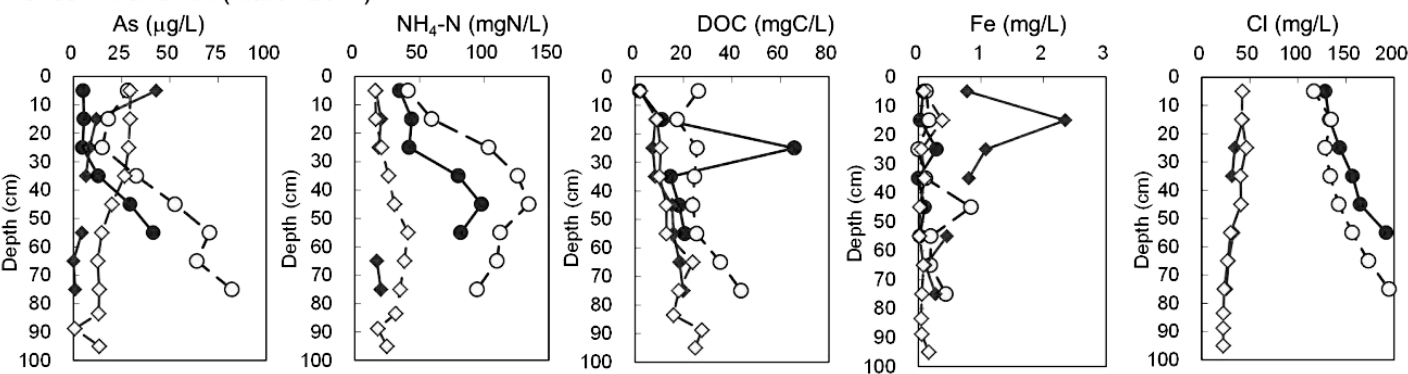

$\sim \mathrm{TM}$ pF3.0 $-\diamond \mathrm{TM}$ pF4.2 $-\mathrm{NH}$ pF3.0 $-\mathrm{O}-\mathrm{NH}$ pF4.2

c) Pond NH (August 2011)
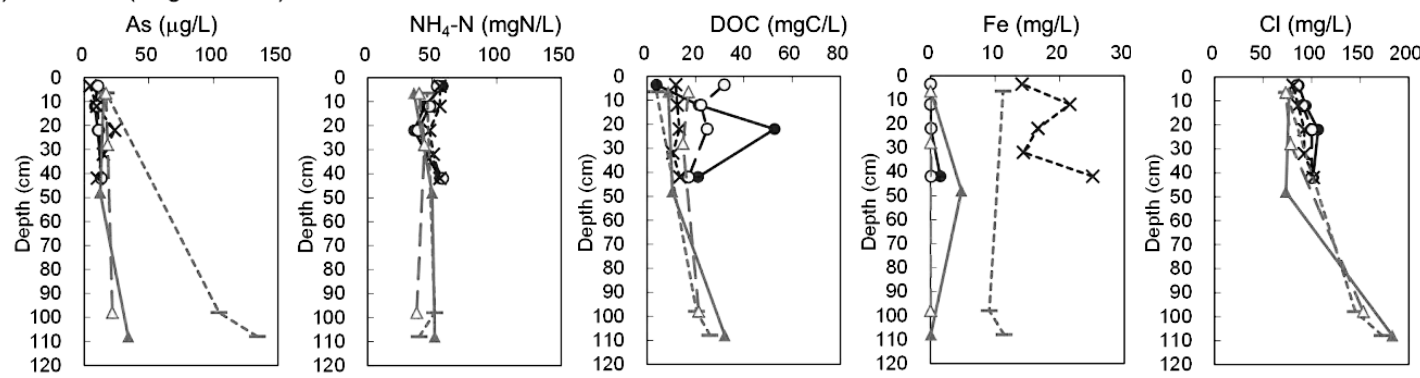

$-\Varangle-\mathrm{NH} 1 \mathrm{pF} 2.3-\mathrm{NH} 1 \mathrm{pF} 3.0-\mathrm{O}-\mathrm{NH} 1 \mathrm{pF} 4.2$

$---\mathrm{NH} 2 \mathrm{pF} 2.3 \rightarrow \mathrm{NH} 2 \mathrm{pF} 3.0-\triangle-\mathrm{NH} 2 \mathrm{pF} 4.2$

図-3 底質間隙水水質の深度分布 

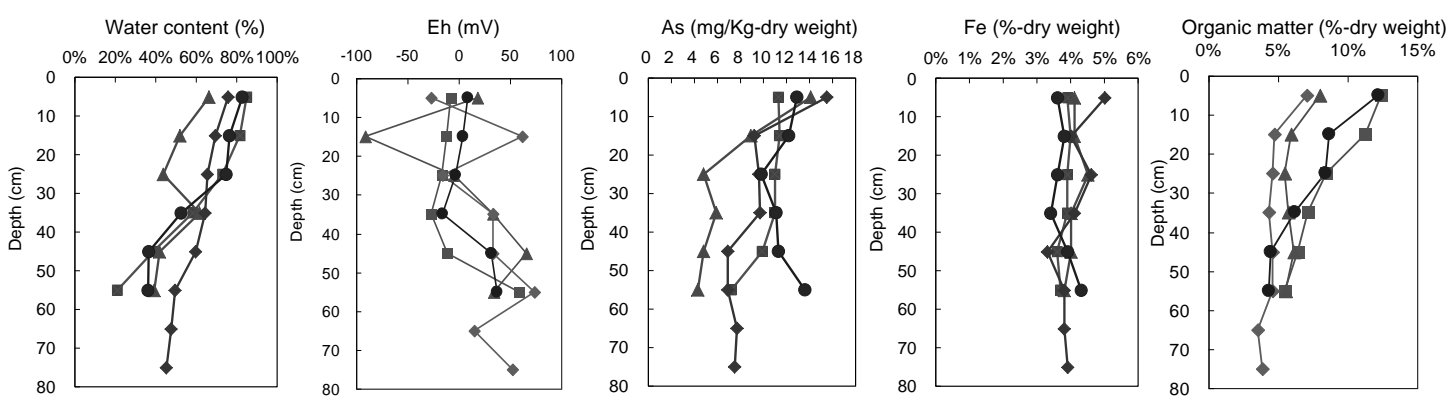

$\rightarrow-\mathrm{TC} \rightarrow \mathrm{SM} \rightarrow-\mathrm{TM} \rightarrow \mathrm{NH}$

図-4 底質の水分含有量、Eh、および化学組成の深度分布

畩のヒ素含有量は2-30 mg/Kg と非常に幅広い值をとるが、 表層から $10 \mathrm{~m}$ 程度の土袞中では $10 \mathrm{mg} / \mathrm{Kg}$ 前後であり、深 さとともに減少している ${ }^{21,30)}$ 。カンボジアでは表層から $14 \mathrm{~m}$ 粘土層ではヒ素含有量は深さ方向に $0.7 \mathrm{mg} / \mathrm{Kg} / \mathrm{m}$ で減少しており ${ }^{17}$ 、八ノイの土壤でも同程度である ${ }^{21,30)}$ これらと比較すると、本調査のため池底質ではため池 NHを除き深さ方向の素含有量の減少量は大きい。

一方、ため池底質中の鉄含有量は4\%前後で深さ方向 にほぼ一定であり、ため池間の差が小さかった。ヒ素 による地下水污染がある土壤中ではヒ素と鉄の含有量 に強い正の相関があることが多い21,30が、底質中ではた め池TMでの夕正の相関（Pearson、 $\rho=0.89 、 P<0.01 ） か ゙$ 見 られた。八ノイの土壌中の鉄含有量は2-5\%程度とため 池底質と同程度であり、七素と同椂に深さとともに $0.1 \% / \mathrm{m}$ 程度、緩やかに減少する ${ }^{21,30)}$

ため池底質の有機物含有量は底質最上部で8.0-12\%、 最下部で4.4-5.9\%であり、ハノイの土㙵の報告值である $1 \%$ 以下 ${ }^{21,30)}$ と比へ顕著に高かった。有機物含有量はい ずれのため池においても底質最上部が最も高く、深さ とともに減少する傾向が見られた。ため池間の差は底 質最上部で最大であった。七素と有機物の含有量はた め池NHを除いたため池TC、SM、TMにおいて正の相関 $(\rho=0.73-0.91 、 P<0.1) \quad$ が見られた。間隙水中の七素濃 度は、ため池TC、SM、TMにおいては底質中の有機物 およびヒ素の含有量と強い正の相関（ $\rho=0.88-0.98$ 、 $P<0.01 ）$ が得られたのに対し、ため池NHでは間隙水ヒ 素濃度と底質中七素含有量との間に有意な相関はなく $(\rho=0.45 、 P=0.19)$ 、底質中有機物含有量とは負の相関 $(\rho=-0.82 、 P=0.02)$ があった。

\section{(4) 安定同位体比}

図-5に池水・地下水 ${ }^{24)}$ ・ 間隙水における酸素安定同位 体比の分布を示した。池水の酸素安定同位体比は-2$11 \%$ c大きなばらつきがあるが、8月および10月に採取

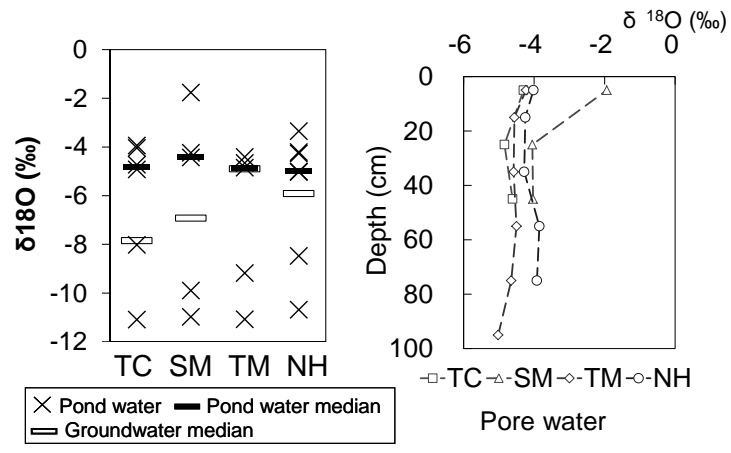

図-5 池水と底質間隙水の酸素安定同位体比

した試料で低く、1月、3月、6月に採取した試料で高い 明確な変動があり、塩化物イオンの季節変動に似てい た。池水の同位体比の中央値は-4-5\%。゙あり、地区間 の差は小さかった。これに対し、地下水においては中 央值の地区間の差はため池の地区差より大きく、地下 水の涵養機構が地区により異なることが示唆された。

間隙水の酸素同位体比は概衩-4-5\%。であり、池水の 同位体比の中央值と同程度の值であった。底質の深さ 方向の同位体比の変化は地区SMの底質最上部を除いて 小さい。ため池TMおよびNHの同位体比は、底質最上 部から梁さ30 $\mathrm{cm}$ にかけて下がり、深さ50 $\mathrm{cm}$ 前後にかけ て上がり、それ以深は再び下がるという傾向が見られ た。上記の同位体比の変動傾向は、水素安定同位体比 にも同様に存在した。

\section{4. 考察}

\section{(1) 池水の起源と水質形成}

調査した4つのため池は主として降水と污水により涵 養されていると考えられた。八ノイ市では年間降水量 の80\%以上が5-9月に集中しており、8月に降水量が最大 
になっている 322 。このため、ハノイの水環境や水質污 染に関する研究では5-9月を雨季とし、10月-4月を乾季 と寸る区分が一般的である ${ }^{23}$,33)。本論文でもこれに倣い 季節を区分すると、池水の塩化物イオン濃度は雨季に 低く、もっとも降水が多い8月に最小值をとった。保存 的な陰イオン濃度の上記のような季節変動は他のモン スーン地域のため池でもみられる ${ }^{34)}$ 。降水が少ない乾 季には塩化物イオンが高くなり、乾季から雨季に移る 前の3月に最大值をとった。また、池水の酸素同位体比 は8月に-10-11\% と最小值をとったが、降水中の酸素同 位体比も 8-9月に-9-11\% と最も低く、池水と同程度の 同位体比であった。降水中の塩化物イオンは常に極め て低濃度である（例えば、大部分が降水に起因する紅 河で $\left.0.8 \mathrm{mg} / \mathrm{L}^{21)}\right)$ のに対し、池水の塩化物イオンの中央 值が10-60 mg/Lであることを考えると、池水は塩化物イ オン濃度が高い水の定常的な供給があったと推定され る。ため池TCを除き、調査したため池は住宅地の中に あり、ため池の周辺（半径200 m) にはため池と水路で つながった農地は存在せず、農業排水等の流入はなか ったと考えられる。このことから、塩化物イオン濃度 の高い水は周辺の集落から排出された生活雑排水やし 尿と推定された。ため池NHは養豚場が隣接しており、 ため池への家畜排水の流入の可能性が考えられる。

池水の塩化物イオン濃度や酸素同位体比の季節変動 は、雨季における降水の流入や蒸発等の影響を受けた ためと考えられる。それに対し、季節変動が比較的小 さいヒ素、DOC、アンモニア性窒素等は、池底に近い 深さ1.5 mにおいて最も高濃度であったことから、污水 の直接の流入に加えて、底質からの溶出が寄与したと 考えられる。底質最上部の間隙水において、塩化物イ オン濃度は、同時に採取した池水の濃度とほぼ同等で あったのに対し、ヒ素、DOC、アンモニア性窒素の濃 度は、底質採取時の池水中の濃度と同等または大きく 上回っていた。

\section{(2) ため池底質における物質の移動・濃集・溶出機構}

底質浅部の間隙水は池水と頻繁な交流があったと考 えられる。4つのため池において、底質浅部は含水率が 66-85\% と高く、底質最上部の間隙水中の塩化物イオン 濃度や酸素安定同位体比は調查時の池水とほぼ等しか った。間隙水と池水との交流が大きい底質の範囲はた め池によって多少異なると考えられるが、ため池SMで は、底質の最上部と深さ20-30 cm（代表深さ $25 \mathrm{~cm}$ ）に おいて酸素安定同位体比が大きく異なっていたことか ら、概祆池底から深さ $20 \mathrm{~cm}$ 以下範囲と考えられる。

間隙水中の酸素安定同位体比はため池 TMやため池 NHでは深さ20-30 cmから深さ50 cm前後にかけてやや上
昇し、再び深さの増加とともに低下していた。この変 動は前述した池水中の同位体比の季節変動（降水之同 様、雨季に低く、乾季に高い）を反映していると考え ると、池水の浸透速度はおよそ $0.6 \mathrm{~m} /$ 年と推定された。 バングラデシュでの研究では、ため池から帯水層への 平均浸透速度は約 $0.67 \mathrm{~m} /$ 年であった ${ }^{35)}$ 。養魚用ため池で 測定された地下浸透速度は、アラバマで7ヶ月間に0.59 $2.6 \mathrm{~m}^{30}$ 、 、゚ナマでは2-5 m/年 ${ }^{37)}$ であった。調査した底質 は概して粒径が小さいシルトであるが、軟らかく流動 性が高いことを考慮すると、推定された池水の浸透速 度は一定の妥当性があると考えられる。

底質中の有機物含有量はすべてのため池において底 質上部で最も高く、深度方向に減少していたのに対し、 間隙水中のDOC濃度は深さとともに増加していた。こ のことは底質中の有機物が時間とともに分解が進み、 その過程で一部が溶存態に移行したためと考えられた。 底質のEhが深さとともに増加したのは、深さとともに 分解性の高い有機物が減少したためと推測された。た め池底質には旧河川由来の堆積物や、污水等の流入、 池に繁茂するハスなどの植生に由来する様々な有機物 が含まれ、ため池底質中でこれらの有機污濁物質が分 解・除去されていたと考えることができる。ため池NH のpF3.0の間隙水試料には、 pF2.3やpF4.2に比べDOCが高 い試料が存在したが、当該底質中で有機物含有量が特 異的に高いわけではなく、有機物が分解しやすい環境 条件にあったと推測された。

2011年3月調査時において、ヒ素とアンモニア性窒素 の濃度が、比較的底質中で自由に動く $\mathrm{pF} 3.0$ の間隙水に 比べ、より固相に強く結びついている $\mathrm{pF} 4.2$ の間隙水が 高かったことは、ため池底質でヒ素やアンモニア性窒 素が固相から液相へ溶出していたことを示唆する。底 質浅部は七素及び有機物含有率が高く、間隙水中にも ヒ素、アンモニア、DOC、鉄（2011年8月調查時のみ） が高濃度で検出されていたことから、還元環境下にお ける七素の溶出が示唆される。ただし、間隙水中のヒ 素やアンモニア性窒素濃度の鉛直分布はため池ごとに 異なっており、ため池の堆積環境や、池水と間隙水々 の交流度合いの違いなどを反映していたと考えられる。 東南アジア及び南アジアの地下水中で溶出する七素 の由来は、七素を含む鉄鉱物の還元溶解 ${ }^{10)}$ と、七素を 含む有機物の分解 ${ }^{11,12)}$ のどちらかと言われている。後者 に関しては、ベンガルデルタにおいて堆積物中のヒ素 と有機物の高い正の相関があり、湿地環境等において 七素と植物由来の有機物が共に堆積したと推定されて いる ${ }^{12)}$ 。ため池TC、SM、TMでは底質中の七素含有量 及び間隙水七素濃度と、底質の有機物含有量との間に 強い正の相関があり、上記のメカニズムのうちヒ素を 
含む有機物の分解が起きていた可能性がある。ヒ素の 濃集につながる生物化学的反応過程は沿岸域のマング ローブ湿地带 ${ }^{38)}$ や水田 ${ }^{12)}$ 、淡水の抽水植物 ${ }^{39)}$ で見られる ことから、池に繁茂するハスなどの植物がヒ素を濃集 し、底質中に高濃度のヒ素をもたらした可能性がある。 ため池底質中でヒ素の溶出が示唆された一方で、底 質がヒ素除去にも寄与寸ることが示唆された。ため池 TC、SM、TMでは、間隙水中ではDOC濃度が高く、ア ンモニア性窒素濃度は底質の深さに伴い上昇しており、 底質中の強い還元性が示唆されたものの、七素濃度は 底質上部で最も高く、深度とともに低下傾向にあった。 これら3つのため池では、前述のようにヒ素が有機物に 由来する可能性が高く、底質の七素含有量が深さとと もに減少する一方で、鉄含有量はほぼ一定であった。 このため、底質中では深さとともにヒ素の溶出速度が 減少し、七素の固相（おそらく底質中の鉄）への吸着 速度がヒ素の溶存態への溶出速度を上回ったため、間 隙水の七素濃度が減少した可能性がある。溶存態の七 素濃度が減少する他の要因には、一般に硫酸イオンの 還元により生成する不溶性の硫化物への七素の吸着 ${ }^{4041)}$ が挙げられるが、間隙水中で硫酸イオンは $1 \mathrm{mg} / \mathrm{L}$ 以下か ら最大 $33 \mathrm{mg} / \mathrm{L}$ で検出されており、還元による硫化物の 生成の可能性は低い。このことは底質のEhが硫酸還元 が起こるEhである-150 mV前後 ${ }^{42)} よ り$ 高いことからも支 持される。

調査したため池のうち、ため池NHは他の3つのため 池之傾向が異なっており、底質中の七素含有量と有機 物含有量や間隙水中の七素濃度の間に有意な相関が見 られなかった。しかし、間隙水中のヒ素、アンモニア 性窒素、およびDOCが最も高濃度であり、深さととも に増加していた。底質のEhは他のため池に比べて差異 は見られなかったが、底質最上部と深さ $55 \mathrm{~cm}$ 比較し た有機物含有量の減少量や底質最上部の有機物含有量 からの減少割合はため池間にややばらつきが見られ、 いずれもため池NHが最大であった。このことは、底質 中での活発な有機物分解を示唆寸る。ため池NHでは養 豚場からの排水が流入しており、底質中の分解しやす い有機物の割合が他のため池に比べ高かった可能性が ある。また、底質中七素含有量は他のため池のように 深さ方向に減少せずにほぼ一定であり、他のため池に 比べて溶出しや寸い形態の七素や鉄が底質下部にも多 く残っていた可能性がある。これらの要因によって、 ため池NHの底質ではヒ素の溶出を伴う還元反応が広い 範囲の深さで起こっており、間隙水中に高いヒ素濃度 がもたらされたと考えられる。

間隙水中の塩化物イオン濃度は、底質上部ではす心゙ てのため池において池水の濃度とほぼ等しかったが、
TC、SM、TMでは深さ方向に一定なのに対し、ため池 NHでは2011年3月及び2011年8月の両調査において深さ とともに上昇していた。この原因として、ため池NH中 の塩化物イオン濃度は25-181 mg/Lと他のため池より変 動幅が大きく、塩化物イオン濃度が高濃度の時期に浸 透した水の影響である可能性や、植物体の風化により 生成する塩素を含む有機物 ${ }^{43)}$ の分解に伴う塩化物イオン の溶出 ${ }^{44} の$ 可能性がある。

\section{(3) ため池浸透水が地下水水質に及ぼす影響}

ため池浸透水の地下水への寄与は主に紅河との位置 関係や水文地質構造により大きく異なると考えられる。 一般に地下水の主な涵養源とされている紅河では、酸 素安定同位体比の単純平均值は-8.4\%。（WISERデータベ 一ス ${ }^{32}$ から算出）、紅河の塩化物イオン濃度は $0.8 \mathrm{mg} / \mathrm{L}$ と報告されている ${ }^{21)}$ 。紅河に隣接する地区TCの地下水 は、酸素安定同位体比が中央值-7.9\%。塩化物イオン濃 度が中央値 $1.4 \mathrm{mg} / \mathrm{L}$ 紅河の值に近く、紅河からの涵養 が主と考えられる。八ノイ市には難透水層が5-10 mの 厚さで地表に広く存在しているが、地区TCが位置する 八ノイ中心部から北西方向の紅河西岸地域では難透水 層が2-3 m と比較的薄く ${ }^{21)}$ 、場所によっては難透水層が 存在せずに更新世の砂層が地表に存在する ${ }^{45)}$ 。そのた め、他の地域に比べてEhが高い酸化的な地下環境にな ったと考えられる。

これに対し、他の3地区では、地下水の塩化物イオン 濃度と酸素安定同位体比は紅河に比べて高く、池水お よびため池の底質から採取した間隙水より低かった。 このため、これらの地下水は、紅河から直接帯水層に 浸透した水と、ため池からの浸透水等の塩化物イオン や同位体比の高い他の水源からの水により涵養されて いたと考えられる。ため池は八ノイ市郊外に多く存在 しており、ため池等で蒸発の影響を受けた水が地下水 の主要な涵養源の一つであるといら酸素安定同位体比 による知見 ${ }^{24}$ からも、ため池からの浸透水が地下水の 涵養源である可能性は高い。特に、紅河から数キロ以 上離れている地区TMやNHでは、地下水の酸素安定同 位体比がため池の中央值と近く、ため池浸透水の割合 が大きかったと推定される。

地中で減衰がほとんどない塩化物イオン濃度をトレ 一サーと考え、仮に紅河とため池水のみが地下水中の 塩化物イオンの起源とし、池水の塩化物濃度の中央值 がため池からの浸透水の平均值と仮定すると、地区SM と地区NHでは地下水のおよそ1/3゙、地区TMでは地下 水のほぼ全量がため池からの浸透水と推定された。

各地区のため池の底質閒隙水と地下水の七素濃度を 比較すると興味深い傾向が見て取れた。すなわち、た 
め池浸透水の影響が大きいと考えられた地区TMや、間 隙水中の七素濃度が高かった地区NHでは地下水中の七 素濃度も顕著に高い傾向があった。紅河そのものの水 はヒ素濃度が4 $\mu \mathrm{g} / \mathrm{L}$ と低い ${ }^{21)}$

ため池浸透水による地下水涵養は、二つの原因で地 下水の七素污染に寄与した可能性がある。一つは底質 間隙水中に含まれる高濃度のヒ素が带水層まで運ばれ ることである。調査した底質下部の間隙水中の七素濃 度をため池から浸透する水の七素濃度と仮定すると、 地区SM、TM、NHにおける地下水中七素濃度はそれぞ れ6、13、20 $\mu \mathrm{g} / \mathrm{L}$ と推定される。この濃度は実際に地下 水中で検出された濃度の半分程度である。もう一つの 原因は、ため池浸透水に含まれる高濃度のDOCが地中 でのヒ素の溶出を誘発することである。紅河の水の $\mathrm{DOC} 2.7 \mathrm{mgCl} / \mathrm{L}^{21)}$ とそれほど高くないのに対し、ため 池からの浸透水は、間隙水データが示すようにDOCが $20 \mathrm{mgCl}$ 前後と非常に高濃度で含まれている。

七素と同様にDOC濃度についてため池浸透水と紅河 の水の混合を考えると、地区SM、TM、NHにおける地 下水中DOC濃度は8.7、20、9.0 mgC/Lと推定されるが、 実際の地下水中DOC濃度の中央值は $1.3 、 2.2 、 3.3 \mathrm{mgCl} / \mathrm{L}$ と推定值よりはるかに低い。地下水中のDOCの由来は ため池浸透水や紅河の水に加えて地層中の有機物も考 えられ、地中でDOCの吸着が起きていた可能性もある が、ため池の浸透水はDOCの分解性が高、20)ことを考 えると、ため池浸透水由来のDOCが地中での高濃度の 七素污染に寄与した可能性がある。

ため池からの浸透水が帯水層まで流動する過程には、 様々な物理化学的および微生物学的なプロセスがある と考えられ、それらの流動過程を考慮せずにため池浸 透水が地下水七素污染を拡大させていると断定するこ とは困難である。また、ため池TC、SM、TMで見られ たように、ため池底質はヒ素を吸着して地下水污染を 防止する役割もあると考えられる。しかしながら、た め池NHのように底質中にヒ素や有機物が豊富に含まれ、 底質における七素溶出が顕著なため池では、底質の定 期的な浚渫により地下水の七素污染を緩和できる可能 性がある。地下における七素の挙動と有機物の影響や、 間隙水中の七素濃度分布がため池によって異なる原因 についてはさらなる研究が求められる。

\section{5. まとめ}

ハノイ市のため池の水質、底質の化学組成、底質間 隙水の水質が明らかになった。ため池の水自体の七素 濃度は低いものの、ため池底質にはヒ素や有機物が豊
富に含まれており、底質間隙水には高濃度の七素、 DOC、アンモニア性窒素が存在することが明らかにな った。間隙水七素濃度が深さ方向に増加するため池と 減少するため池があり、ため池底質ではヒ素の溶出と 吸着の両方が起きていると考えられた。また、ため池 浸透水の地下水涵養への寄与が大きい地域や、底質間 隙水中の七素濃度が高い地域では、地下水の七素濃度 も高い傾向があった。ため池浸透水が帯水層まで流動 する過程には様々な水質変動要因が考えられるものの、 ため池からの浸透水が地下水の七素污染の一因となっ ている可能性が示唆された。

謝辞 : 本研究は、平成21年度採択・科学技術振興機構 CREST（研究領域：持続可能な水利用を実現する革新的 な技術とシステム、テーマ「気候変動に適応した調和型 都市圈水利用システムの開発」）の援助を受けて行われ たことを記して謝意を表する。

\section{参考文献}

1) PPJ-VIAP-HUPI: Hanoi capital construction master plan to 2030 and vision to 2050, Hanoi People's Committee (HPC), Hanoi, Viet Nam, 2011.

2) Berg M., Tran H.C., Nguyen T.C., Pham H.V., Schetenleib R. and Giger W.: Arsenic contamination of groundwater and drinking water in Vietnam: a human health threat, Environmental Science \& Technology, Vol. 35, No. 13,pp. 2621-2626, 2001.

3) Dan N.V. and Dung N.T.: Groundwater pollution in the Hanoi Area, Vietnam., Available from: http//www.unescap.org/esd/Energy-Securityand-Water-Resources/water/publications/CD/escapiwmi/waterquality/Groundwater\%20pollution\%20in\%20the\%20Hanoi \%20area,\%20Vietnam.pdf/, 2002.

4) Nga T.T.V., Inoue M., Khatiwada N.R. and Takizawa S.: Heavy metal tracers for the analysis of groundwater contamination: Case study in Hanoi City, Water Science \& Technology: Water Supply, Vol. 3, pp. 343-350, 2003.

5) Berg M., Stengel C., Trang P.T.K., Hung Viet P., Sampson M.L., Leng M., Samreth S. and Fredericks D.: Magnitude of arsenic pollution in the Mekong and Red River Deltas - Cambodia and Vietnam, Science of The Total Environment, Vol. 372, No. 2-3, pp. 413-425, 2007.

6) Winkel L.H.E., Pham T.K.T., Vi M.L., Stengel C., Amini M., Nguyen T.H., Pham H.V. and Berg M.: Arsenic pollution of groundwater in Vietnam exacerbated by deep aquifer exploitation for more than a century, Proceedings of the National Academy of Sciences of the United States of America, Vol. 108, No. 4, pp. 1246-1251, 2011.

7) Sharma V.K. and Sohn M.: Aquatic arsenic: toxicity, speciation, transformations, and remediation, Environment International, Vol. 35, No. 4, pp. 743-759, 2009.

8) Berg M., Luzi S., Trang P.T.K., Viet P.H., Giger W. and Stüben D. Arsenic removal from groundwater by household sand filters: comparative field study, model calculations, and health benefits, Environmental Science \& Technology, Vol. 40, No. 17, pp. 5567-5573, 2006.

9) An D.T., Kuroda K., Takizawa S., Hayashi T., Nga T.T.V. and Oguma 
K.: Household survey of installation and treatment efficiency of point-ofuse water treatment systems in Hanoi, Vietnam, Journal of Water Supply: Research and Technology - Aqua, in press, 2013.

10) Fendorf S., Michael H.A. and van Geen A.: Spatial and temporal variations of groundwater arsenic in South and Southeast Asia, Science, Vol. 328, No. 5982,pp. 1123-1127, 2010.

11) Blute N.K., Brabander D.J., Hemond H.F., Sutton S.R., Newville M.G. and Rivers M.L.: Arsenic sequestration by ferric iron plaque on cattail roots, Environmental Science \& Technology, Vol. 38, No. 22, pp. 6074 6077,2004

12) Meharg A.A., Scrimgeour C., Hossain S.A., Fuller K., Cruickshank K., Williams P.N., Kinniburgh D.G.: Codeposition of organic carbon and arsenic in Bengal Delta aquifers, Environmental Science \& Technology, Vol.40, No. 16,pp. 4928-4935, 2006.

13) Smedley P.L. and Kinniburgh D.G.: A review of the source, behaviour and distribution of arsenic in natural waters, Applied Geochemistry, Vol. 17, No. 5, pp. 517-568, 2002.

14) Kinniburgh D.G. and Smedley P.L.: Arsenic Contamination of Ground Water in Bangladesh, BGS Technical Report WC/00/19, British Geological Survey, Keyworth, UK, 2001.

15) Harvey C.F., Swartz C.H., Badruzzaman A.B. M., Keon-Blute N., Yu W., Ali M.A., Jay J., Beckie R., Niedan V., Brabander D., Oates P.M., Ashfaque K.N., Islam S., Hemond H.F. and Ahmed M.F.: Arsenic mobility and groundwater extraction in Bangladesh, Science, Vol. 298, No. 5598,pp. 1602-1606, 2002.

16) McArthur J.M., Ravenscroft P., Banerjee D.M., Milsom J., HudsonEdwards K.A., Sengupta S., Bristow C., Sarkar A., Tonkin S. and Purohit R.: How paleosols influence groundwater flow and arsenic pollution: A model from the Bengal Basin and its worldwide implication, Water Resources. Research, Vol. 44, No. 11, W11411, 2008.

17) Polizzotto M.L., Kocar B.D., Benner S.G., Sampson M. and Fendorf S.: Near-surface wetland sediments as a source of arsenic release to ground water in Asia, Nature, Vol. 454, No., 7203, 505-U5, 2008.

18) Rowland H.A.L., Pederick R.L., Polya D.A., Pancost R.D., Van Dongen B.E., Gault A.G., Vaughan D.J., Bryant C., Anderson B. and Lloyd J.R. The control of organic matter on microbially mediated iron reduction and arsenic release in shallow alluvial aquifers, Cambodia. Geobiology, Vol. 5, No. 3, pp. 281-292, 2007.

19) Mladenov N., Zheng Y., Miller M.P., Nemergut D.R., Legg T., Simone B., Hageman C., Rahman M.M., Ahmed K.M. and McKnight D.M.: Dissolved organic matter sources and consequences for iron and arsenic mobilization in Bangladesh aquifers, Environmental Science \& Technology, Vol. 44, No. 1, pp. 123-128, 2009.

20) Neumann R.B., Ashfaque K.N., Badruzzaman A.B.M., Ashraf Ali M., Shoemaker J.K. and Harvey C.F.: Anthropogenic influences on groundwater arsenic concentrations in Bangladesh, Nature Geoscience, Vol. 3, No. 1,pp. 46-52, 2010.

21) Berg M., Trang P.T.K., StengelC., Buschmann J., Viet P.H., Van Dan N., Giger W. and Stiiben, D.: Hydrological and sedimentary controls leading to arsenic contamination of groundwater in the Hanoi area, Vietnam: the impact of iron-arsenic ratios, peat, river bank deposits, and excessive groundwater abstraction, Chemical Geology, Vol. 249, No. 1-2, pp. 91112, 2008.

22) Water Master Plan of Hanoi City for the Period of 1993-2010. Vol. 1, 1993.

23) Norman J., Sparrenbom C.J., Berg M., Nhan D.D., Nhan P.Q., Rosqvist H., Jacks G., Sigvardsson E., Baric D., Moreskog J., Harms-Ringdahl P. and Hoan N.V.: Arsenic mobilisation in a new well field for drinking water production along the Red River, Nam Du, Hanoi, Applied
Geochemistry, Vol. 23, No. 11, pp. 3127-3142, 2008.

24) Hayashi T., Kuroda K., An D.T., Nga T.T.V. and Takizawa S.: Interaction between surface water areas and groundwater in Hanoi city, Viet Nam, Proc. of AGU Fall Meeting, H11D-1208, 2012.

25) 黒田啓介, 林武司, 渡邊直子, Nga T.T.V., 滝沢智: ベトナム・八 ノイ市のため池底質中間隙水と周辺地下水におけるヒ素分 布,第 46 回水環境学会年会講演集, 2012.

26) Trafford J.M., Lawrence A.R., Macdonald D.M.J., Nguyen V.D., Tran D.N. and Nguyen T.H.: The effect of urbanisation on the groundwater quality beneath the city of Hanoi, Vietnam, BGS Technical Report WC/96/22, British Geological Survey, Keyworth, UK, 1996.

27) Tanabe S., Saito Y., Lan Vu Q., Hanebuth T. J. J., Lan Ngo Q. and Kitamura A.: Holocene evolution of the Song Hong (Red River) delta system, Northem Vietnam, Sedimentary Geology, Vol. 187, No. 1-2, pp. 29-61, 2006.

28) 箭内寛治, 飯竹重夫: $\mathrm{pF}$ の原理と応用: 4. $\mathrm{pF}$ の工学的応用 （その 1）,土と基礎,Vol.35, No.2,pp.99-105, 1987.

29) 風早康, 安原正, 高橋浩, 森川徳, 大和田道, 戸崎裕, 浅井和: 同 位体・希ガストレーサーによる地下水研究の現状と新展開, 日本水文科学会誌, Vol.37, No.4,pp. 221-252, 2007.

30) Eiche E., Neumann T., Berg M., Weinman B., van Geen A., Norra S., Berner Z., Trang P.T.K., Viet P.H. and Stüben, D.: Geochemical processes underlying a sharp contrast in groundwater arsenic concentrations in a village on the Red River delta, Vietnam, Applied Geochemistry, Vol. 23, No. 11, pp. 3143-3154, 2008.

31) Shotbolt L:: Pore water sampling from lake and estuary sediments using Rhizon samplers, Joumal of Paleolimnology, Vol. 44, No. 2, pp. 695-700, 2010.

32) IAEA: WISER Database. Available from: http://wwwnaweb.iaea.org/napc/ih/IHS resources isohis.html.

33) Hung D.Q. and Thiemann W.: Contamination by selected chlorinated pesticides in surface waters in Hanoi, Vietnam, Chemosphere, Vol. 47, No. 4,pp. 357-367, 2002.

34) Sengupta S., McArthur J. M., Sarkar A., Leng M. J., Ravenscroft P., Howarth R.J. and Banerjee D.M.: Do ponds cause arsenic-pollution of groundwater in the Bengal Basin? An answer from West Bengal, Environmental Science \& Technology, Vol. 42, No. 14, pp. 5156-5164, 2008.

35) Stute M., Zheng Y., Schlosser P., Homeman A., Dhar R.K., Datta S., Hoque M.A., Seddique A.A., Shamsudduha M., Ahmed K.M., van Geen A.: Hydrological control of As concentrations in Bangladesh groundwater, Water Resources Research, Vol. 43, No. 9, W09417, 2007.

36) Boyd C.E.: Hydrology of small experimental fish ponds at Auburn, Alabama, Transactions of the American Fisheries Society, Vol. 111, No. 5, pp. 638-644, 1982.

37) Teichert-Coddington D.R., Peralta M. and Phelps R.P.: Seepage reduction in tropical fish ponds using chicken litter, Aquacultural Engineering, Vol. 8, No. 3, pp. 147-154, 1989.

38) Kirby J., Maher W., Chariton A. and Krikowa F.: Arsenic concentrations and speciation in a temperate mangrove ecosystem, NSW, Australia, Applied Organometallic Chemistry, Vol.16, No. 4, pp. 192-201, 2002.

39) Chen Z., Zhu Y., Liu W. and Meharg A.A.: Direct evidence showing the effect of root surface iron plaque on arsenite and arsenate uptake into rice (Oryza sativa) roots, New Phytologist, Vol.165, No. 1, pp. 91-7, 2005.

40) Lowers H.A., Breit G.N., Foster A.L., Whitney J., Yount J., Uddin M.N. and Muneem A.A.: Arsenic incorporation into authigenic pyrite, Bengal Basin sediment, Bangladesh, Geochimica et Cosmochimica Acta, Vol. 71, No. 11,pp. 2699-2717, 2007.

41) Buschmann J. and Berg M.: Impact of sulfate reduction on the scale of 
arsenic contamination in groundwater of the Mekong, Bengal and Red River deltas, Applied Geochemistry, Vol. 24, No. 7, pp. 1278-1286, 2009.

42) Appelo C.A.J. and Postma D.: Geochemistry, groundwater and pollution 2nd edition: Balkema, the Netherlands, 2005.

43) Myneni S.C.B.: Formation of stable chlorinated hydrocarbons in weathering plant material, Science, Vol. 295, No. 5557, pp. 1039-1041, 2002.

44) Kauffman S., Royer D., Chang S. and Bermer R.: Export of chloride after clear-cutting in the Hubbard Brook sandbox experiment, Biogeochemistry, Vol. 63, No. 1, pp. 23-33, 2003.
45) Tam V.T.: Groundwater in Hanoi City Over- or Inappropriate exploitation?, Proc. of CREST Symposium associated with 10th SEAWE in Hanoi, "Development of Well-Balanced Urban Water Use Systems Adapted for Climate Change-Toward Sustainable Water Use-", 2012.

\title{
Influence of Pond Seepage on Groundwater Pollution by Arsenic in Hanoi, Viet Nam
}

\author{
Keisuke KURODA ${ }^{1}$, Takeshi HAYASHI ${ }^{2}$, Naoko WATANABE ${ }^{3}$, Kumiko OGUMA $^{1}$, \\ $\mathrm{Nga} \mathrm{TRAN}^{4}$ and Satoshi TAKIZAWA ${ }^{1}$ \\ ${ }^{1}$ Dept. of Environmental Engineering, The University of Tokyo \\ ${ }^{2}$ Faculty of Education and Human Studies, Akita University \\ ${ }^{3}$ Graduate School of Engineering, Hokkaido University \\ ${ }^{4}$ National University of Civil Engineering, IESE, DHXD, 55 Giai Phong Street, Hanoi, Viet Nam
}

Ponds are abundantly found in suburban area of Hanoi City, Viet Nam, where groundwater pollution by arsenic is a major problem. We investigated water quality of pond waters, pore waters of pond sediments, and chemical property of pond sediments in four ponds in Hanoi suburbs in order to estimate the influence of pond seepage on groundwater pollution by arsenic. While pond waters had low arsenic levels $(<10 \mu \mathrm{g} / \mathrm{L})$, pore waters had high levels of arsenic (maximum: $134 \mu \mathrm{g} / \mathrm{L}$ ), indicating the dissolution of arsenic from arsenic- and organic matter-rich pond sediments. It was also suggested that pond sediments not only released arsenic but also adsorbed arsenic from the dissolved phase, mitigating groundwater pollution by arsenic. Analysis of chloride and stable isotopes $\left(\delta^{18} \mathrm{O}, \delta \mathrm{D}\right)$ indicated that seepage from ponds was a significant source of recharge of groundwater which was polluted by high levels of arsenic (median: 27 and $43 \mu \mathrm{g} / \mathrm{L}$ ). 